\section{Where Is My Biographical Directory?}

\section{Patricia Spellman}

American Political Science Association

At last, the 1988 APSA Biographical Directory is off the presses. If you are one of the 1,500 members who ordered the directory last year at a special prepublication price of $\$ 20.00$, your directory is in the mail or already in your hands. Our printer, Carleton Graphics, in South Bend, Indiana, agreed to send the books by fourth class mail on August 22.

Additional copies may be ordered by writing to: APSA Publications, $1527 \mathrm{New}$ Hampshire Avenue, NW, Washington, DC 20036. The price is now $\$ 25$ for members plus $\$ 2.50$ for postage and handling. Nonmembers pay $\$ 35$ plus $\$ 2.50$. (It's important to enclose a check with your order.)

Why does it take so long to produce the directory? may be your next question. If you multiply the information on one form by 6,000 (the number of our respondents), you will get some idea of the massive amount of data that was typeset and proofread for a book of this nature. The chief delay, however, which held up production by six or seven months, was the difficulty in reading handwritten questionnaire forms.

A team of typesetters at Carleton did a heroic job of interpreting the forms but, unfortunately, were not able to correctly guess at all of the information. It was up to the APSA staff to locate and correct the hundreds of misunderstandings that appeared in the first computer printout of the directory. It may be illuminating, and amusing, to see samples of how idiosyncratic handwriting looks to outsiders. The examples below are followed by the official APSA interpretation.

General Alorizos, Senior Advisor

Brod Origs Inst, Brookings Inst

Fairhigh Michigan U, Fairleigh Dickinson

Drought in the School, Drought in the Sahel

Sen Lenserett Salharsharll, Sen Leverett

Saltonstall
Balanced Budgets \& State Surprises, ... State Surpluses

Tenuosities, Tenuous Ties

In Search of Paws, .... of Power

Disenoriented Realists, Disenchanted Realists

Urarisnatic Hirs, Charismatic Hero

Secured Harassment, Sexual Harassment

Farmers of Constitution, Framers of . . .

Trends \& Camelot, Trends \& Correlates

Future Groups with Wether Lite, Interest

Groups in the Western States

All Tub Structure, Attitude Structure

Reticnal Clinic, Rational Choice

We hope that all errors were duly corrected, and it's our sincere wish that each member will be happy with his or her entry.

\section{Clarence Berdahl Claims Longest Membership}

\section{Jean Walen}

American Political Science Association

PS has had several corrections to our story on "Persons with Longest Association Memberships" in the Spring 1988 issue because of the "year joined" being recorded incorrectly in our records. We welcome any further corrections to our story and records.

Clarence Berdahl, who just celebrated his 98th birthday in June, wrote in a very firm hand:

Last night I was reading the latest PS (Spring 1988) and got quite a shock when I came to the list of "Persons with Longest Association Memberships" (p. 316) and found myself listed with "Members since 1927." I do not have receipts or other evidence of payment of membership dues for the earliest years, but I came to the University of Illinois as a graduate student in October 1917, and probably became a member at once in view of my close association with Professors james W. Garner and John A. Fairlie, also Robert Cushman. At any rate, 1 certainly became a member when I returned in January 1919 from war service. In 1923 Professor Fairlie was away on a year's leave, and I served as Acting Managing Editor of the American Political Science 